\title{
Entrepreneurship Preference among University Students: an Evidence of Entrepreneurship Education Program
}

\author{
Ambara Purusottama ${ }^{\bowtie}$, Teuku Fajar Akbar \\ School of Business and Economics, Universitas Prasetiya Mulya, Tangerang, Indonesia
}

\section{Info Article}

History Article:

Submitted 14 September 2019

Revised 29 October 2019

Accepted 8 November 2019

\section{Keywords:}

Entrepreneurahip Education Program; Entrepreneurial Preference; Theory of Planned Behavior.

\begin{abstract}
This study aims to answer the effectiveness of EEP toward entrepreneurial preference in Indonesia. Entrepreneurship Education Program (EEP) has become one of the main instruments of growth of many governments around the world, including the Indonesian government. Nevertheless, polemics and debates have arisen in Indonesia regarding its implementation effectiveness. Through this study, we also emphasize the utilization of family (parents') work background to understand the effectiveness of EEP further. Surveys among university students were conducted in this research, particularly to those who were exposed to EEP during their studies. By using the Theory of Planned Behavior (TPB), the findings conveyed that EEP is indeed effective and in line with students' entrepreneurial preferences. Of the three factors, only subjective norms have a contradicting relationship. Similar results occur using family work background, i.e., families with entrepreneurial-work backgrounds and families who do not have an entrepreneurial-work background. This research contributes to the behavioral theory, particularly in mitigating EEP polemics among researchers and practitioners, as well as assess the effectiveness of EEP.
\end{abstract}

\section{Mengukur Preferensi Kewirausahaan Mahasiswa: Studi Kasus Program Pendidikan Kewirausahaan}

\begin{abstract}
Abstrak
Penelitian ini bertujuan untuk menjawab efektivitas EEP terhadap preferensi kewirausahaan di Indonesia. Program Pendidikan Kewirausahaan (EEP) menjadi instrumen pemerintah untuk mengejar ketertinggalan kewirausahaan dari bangsa lain. Meskipun demikian, implementasi EEP yang masih berpolemik menimbulkan keraguan akan efektivitas EEP dalam konteks Indonesia. Dalam studi ini, kami juga mendorong penggunaan latar belakang pekerjaan keluarga untuk memahami lebih jauh mengenai efektivitas EEP. Penelitian ini menggunakan survey terhadap mahasiswa yang terpapar EEP dalam studinya. Dengan menggunakan Theory of Planned Behavior (TPB), temuan menunjukkan bahwa EEP berjalan efektif terhadap preferensi kewirausahaan mahasiswa. Dari ketiga faktor, hanya faktor norma subjektif yang memiliki hubungan berkebalikan. Hasil yang serupa terjadi dengan menggunakan latar belakang pekerjaan keluarga. Penelitian ini berkontribusi bagi teori perilaku untuk membantu menjawab polemik EEP dan juga menjadi penilai efektivitas EEP.
\end{abstract}

JEL Classification: M20, M21

How to Cite: Purusottama, A., \& Akbar, T. F. (2019). Entrepreneurship Preference among University Students: an Evidence of Entrepreneurship Education Program. Jurnal Dinamika Manajemen, 10(2), 185-196. 


\section{INTRODUCTION}

The implementation of the Entrepreneurship Education Program (EEP) in Indonesia is in line with the country's endeavor to transform and improve entrepreneurship in Indonesia. To catch up with other countries, the Indonesian government implements entrepreneurial-based education in a mandatory form of curriculum, especially in higher education. This reasoning is supported by previous research that found that educational programs are capable of producing significant entrepreneurial impacts for individuals (Fayolle, 2013; Fayolle \& Gailly, 2015). The government tries to implement EEP from an early age, which they considered to be more effective. Students are potential figures to implement entrepreneurship (Purusottama \& Akbar, 2019). Nevertheless, there are also studies that are also not-pro towards EEP programs due to its minimal impact. Indeed, the discussion on the role of the EEP has not yet come to a firm conclusion (Purnomo, 2015; Purusottama, 2019).

The lengthy discussion does not stop there due to the fact that experts' arguments were supported by a strong and convincing theoretical foundation (Nabi et al., 2017). However, we see that EEP discussions tend to focus more on the output of education in the form of entrepreneurial skills or managerial skills. We assume these measurements cannot be carried out directly because students are still in the process of learning and identity searching (Nielsen \& Gartner, 2017). Furthermore, the process that occurs among students varies depending on the absorption ability of students who are influenced by many factors, not just cognitive abilities. We emphasize the measurement of entrepreneurship from the perspective of student entrepreneurial preferences such as their willingness to start a business or through the perspective of the practical output of the educational process, which is on career choices when becoming an entrepreneur. We see that the perspective of measurement using student ent- repreneurial preferences needs to be done with a viable human behavioral approach (Schlaegel \& Koenig, 2014).

To measure individual entrepreneurial behavior resulting from entrepreneurshipbased education, we use the theory of planned behavior as conducted by previous research (Kautonen et al., 2015). According to the stu$\mathrm{dy}$, human behavior is driven by several primary factors namely: attitudes, subjective norms, and behavior control. TPB is a behavior model that has been used by other studies to understand individual and/or organizational behavior, including entrepreneurial behavior. The three factors mentioned earlier-attitudes, subjective norms and behavior control-do not directly influence behavior. Individual intentions are the closest and most predictable output compared to the behavior of the three factors in the context of entrepreneurship (Ajzen \& Sheikh, 2013).

Those three factors that make-up TPB have a relationship that influences one another. Attitude is an internal factor that affects individuals in behavior or interest as an assessment of the responses obtained. If individuals feel that entrepreneurship has a positive value and could provide them benefits, the individual will tend to respond positively. Attitudes are driven by the knowledge they have and also past experiences, whereas subjective norms are the basis for assessing individuals who are influenced by their social environment. The social environment is the closest people or community figures that have an influence on the individual. If the social opinion on entrepreneurship resulted in a positive assessment, then a positive response is bound to occur. Lastly, behavioral control is the individual's self-confidence towards something. If the individual feels that entrepreneurship activities can be executed, then the individual will bound to give a positive response. Vice versa, if the individual sees that entrepreneurship activities are challenging, the individual will bound to give a negative response. These factors can be used as a guide for measuring entrepreneurial behavior. 
The measurement of entrepreneurial behavior becomes very important to discuss as it is a manifestation of EEP intervention (Küttim et al., 2014). Behavior is also a relatively complex manifestation of humans, so that often studying behavior becomes the biggest challenge for researchers. For this reason, shifting from behavior to intention becomes relevant to do because it is still in the same corridor and is also easier to predict (Miralles et al., 2017). We believe that the results of EEP would be more relevant if measured by using students' preferences towards entrepreneurship (Westhead \& Solesvik, 2016). Nevertheless, the ultimate conclusion in previous studies has never been reached. Therefore, we consider it urgent and essential to measure student entrepreneurial behavior with the following approach.

RQ1: How effective are entrepreneurship preferences among university students in the context of EEP?

In measuring student behavior, we are aware that family background has a strong influence. Whatever the student chooses the choice of university major, the family is the dominant figure in individual career preferences in the future (Castro et al., 2015). There is a powerful correlation between individual careers and family careers (Bosma et al., 2012). Therefore, we can sum up that family background cannot be separated into student entrepreneurial behavior (Eesley \& Wang, 2017). Although the study of student career choices has been widely studied, specific studies with regard to career choices in the context of EEP unfortunately still lacks. For this reason, a family background study on entrepreneurial preferences of students exposed to EEP is conducted.

RQ2: How strong is the correlation between a parent's background towards entrepreneurship preferences among university students in the context of EEP?

Moreover, this study aims to explain the impact of EEP on entrepreneurial preferences among students in the context of Indonesian higher education. The conceptual framework of this study can be seen in Figure 1.

The novelty of this research is that simultaneously the research brings a focal point on the occupation of parents in relation to forming entrepreneurial preferences as a control variable. By using TPB, we seek to find out the effectiveness of EEP toward two variables; intention to create new ventures and intention to become entrepreneurs as professions.

This study uses quantitative surveys among university students that are exposed by EEP in the Greater Jakarta area. The theoretical contribution of the study can be utilized as an intermediary for further discussions on the role of EEP for university students who have not made up their mind when it comes to selecting professions that they are going to pursue in the future. For practitioners, this study is able to be used as a reference to develop an EEP curriculum in order to improve the current higher educational model.

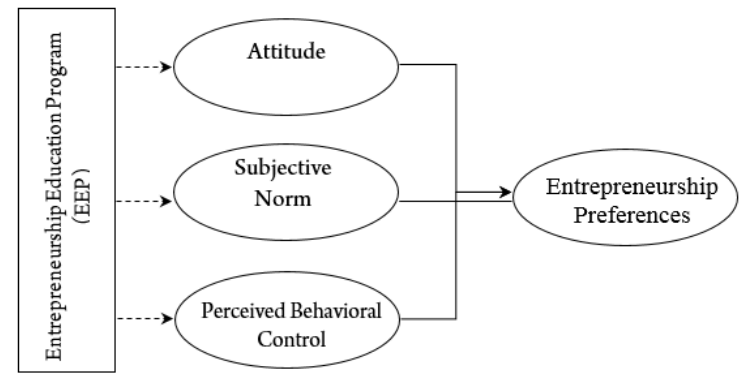

Figure 1. Conceptual Framework

\section{Hypothesis Development}

Attitude is a factor in an individual that is learned in order to receive a positive or negative response including in entrepreneurial activities, known as Entrepreneurial attitudes (ATT) (Liñán et al., 2011). Feelings are determined by one's belief based on the consequences of his/her past actions (Ajzen \& Sheikh, 2013). Ajzen claims that attitudes represent an appraisal of psychological objects occupied in the opposing negative and positive attitudes dimensions. Attitudes can shift due to the valence in beliefs (Gorgievski et al., 2018). In the context of entrepreneurship, ATT can be described as an individual responding positively when his/her business brings benefits and responding 
negatively when it does not. On the other hand, in the professional attraction context, ATT can be explained as the desire to be self-employed when having a business is considered to be beneficial or to remain working in an company when it is not.

$\mathrm{H} 1$ : The students' attitude has significant and positive impacts toward intention to create a new venture

H2: The students' attitude has significant and positive impacts on the entrepreneur as a professional attraction

Subjective Norms (SUB) is a tool to measure social pressure to become entrepreneurs (Liñán et al., 2011). Specifically, SUB points to the perception of the persons considered to be the "point of reference" who will approve the decision of whether or not one becomes an entrepreneur (Gorgievski et al., 2018). TPB refers to SUB as the perception or opinion of other individuals who are considered important when one decides to act. The opinion may alter one's view, influence, and motivate to which the opinion is intended for. As a result, SUB can be defined as social pressure that comes from someone who is considered important when one takes action. Prior researches have mentioned that SUB plays an essential role in human behaviors, especially those that underlie intention and attitudes. With regard to entrepreneurial activities, when an individual becomes an entrepreneur, he or she will be influenced by other individuals who are considered essential. Surrounding opinions on becoming an entrepreneur have a great tendency to lead that particular individual to follow that opinion.

H3: Intention to create a new venture is significantly and positively affected by the students' subjective norm.

H4: Entrepreneur as a professional attraction is significantly and positively affected by the students' subjective norm.

Perceived Behavior Control (PBC) is the perception of the level of difficulties of becoming an entrepreneur (Gorgievski et al., 2018). Referring to TPB, PBC is the impres- sion of the ease and difficulty of taking action reflected in past experiences and the anticipations of future obstacles. PBC is closely related to the theory of self-efficacy developed by Bandura in 1997. He suggests that self-efficacy is someone's belief related to his ability to produce a certain level of performance that affects events influencing their lives. Self-efficacy decides how individuals feel, think, inspire, and behave themselves. Such beliefs create differing impacts through four noteworthy processes, including cognitive, motivational, affective, and determination processes.

H5: Perceived behavioral control of the students' has a significant and positive impact on the intention to create a new venture.

H6: Perceived behavioral control of the students' has a significant and positive impact towards professional attraction.

The detail of research framework can be seen in Figure 2.

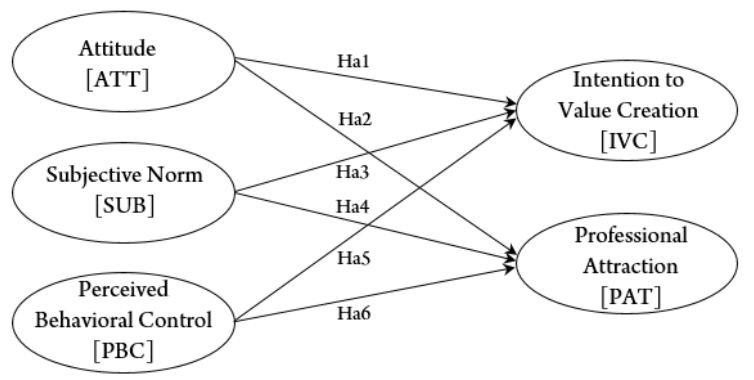

Figure 2. Research Framework and Hypothesis Development

\section{METHOD}

We use a positivist paradigm as a methodological approach to this study. This quantitative study was conducted by distributing directly 1,000 questionnaires offline and online, to students who majored in management and entrepreneurship in the Jabodetabek (Jakarta, Bogor, Depok, Tangerang, Bekasi) area. Students have great potential and a strong tendency to become an entrepreneur in the future (Purusottama \& Akbar, 2019). The conceptual framework of this research emphasizes the stu- 
Ambara Purusottama \& Teuku Fajar Akbar/ Entrepreneurship Preference among University Students: an....

dents' interest in doing business and also works as an entrepreneur. The research instrument was distributed and successfully obtained 631 valid responses. The response rate was 63.2 percent. This higher response rate was due to the fact that we used our colleague network from other universities, particularly through university student boards, which greatly supported the distribution of questionnaires to their classmates or colleagues.

\section{Measurement}

Questionnaire statements were built and rated using a Likert scale ( $1=$ Strongly disagree to $7=$ Strongly agree). A measurement scale of 5 or more would show better results compared to the measurement scale below (Böckenholt, 2017). The data were analyzed using the software that supports statistical calculations. In this study, we used AMOS version 24 software to support the model building and analysis.
During the preparation of statements, several previous studies were referred to and then adjusted to Bahasa as the everyday language used by the respondents. This adjustment was aimed to make it easier for the respondents to understand the statements and in answering the questionnaires. The research instrument used four statements to measure attitudinal variables adopted from previous research (Liñán \& Chen, 2009; Solesvik et al., 2012). Respondents were asked to assess whether entrepreneurship was considered positive or not. The detail of the research instrument can be seen in Table 1 .

We also referred to Souitaris et al. (2007) and Solesvik et al. (2012) to compile statements used in SUB variables. Respondents were asked to assess the influence of the social environment in entrepreneurship, including family, friends, and others who had a major influence on themselves in the context of entrepreneurship. Three statements were used to measure the influence of the social environment.

Table 1. Research Instrument

\begin{tabular}{|c|c|c|}
\hline Variables & Statements & Code \\
\hline \multirow{4}{*}{$\begin{array}{l}\text { Attitude } \\
\text { (ATT) }\end{array}$} & Doing business has positive benefits for me. & ATT_1 \\
\hline & Doing business is something that I can be proud of. & ATT_2 \\
\hline & Starting a business also benefits the surrounding environment. & ATT_3 \\
\hline & I have lots of interest in doing business. & $\mathrm{ATT} \_4$ \\
\hline \multirow{3}{*}{$\begin{array}{l}\text { Subjective Norms } \\
\text { (SUB) }\end{array}$} & My family hopes that I will become an entrepreneur. & SUB_1 \\
\hline & My closest friend says that I should be an entrepreneur. & SUB_2 \\
\hline & The person that I look up to encourages me to become an entrepreneur. & SUB_3 \\
\hline \multirow{4}{*}{$\begin{array}{l}\text { Perceived Behav- } \\
\text { ioral Control } \\
\text { (PBC) }\end{array}$} & If I want, I can immediately become an entrepreneur. & PBC_1 \\
\hline & When deciding on starting a new business, all decisions are in my hand. & PBC_2 \\
\hline & I am fully in control of my business. & PBC_3 \\
\hline & If I want, I can immediately become an entrepreneur. & PBC_1 \\
\hline \multirow{5}{*}{$\begin{array}{l}\text { Intention tc } \\
\text { Creation } \\
\text { (IVC) }\end{array}$} & I will do anything in order to create a new venture & IVC_1 \\
\hline & I am ready to start a business and ready to run a business now & IVC_2 \\
\hline & I have the ability to start a business & IVC_3 \\
\hline & I seriously want to start a business & IVC_4 \\
\hline & I want to do business as soon as possible & IVC_5 \\
\hline \multirow{4}{*}{$\begin{array}{l}\text { Professional At- } \\
\text { tractiveness } \\
(\mathrm{PAT})\end{array}$} & I am interested in becoming an entrepreneur & PAT_1 \\
\hline & My career goal is to become an entrepreneur & PAT_2 \\
\hline & If I have the opportunity, I will choose to become an entrepreneur & PAT_3 \\
\hline & Of all the professions that exist today, I prefer to be an entrepreneur & PAT_4 \\
\hline
\end{tabular}


The behavioral control variable also used three statements adopted from previous research (Souitaris et al., 2007; Liñán \& Chen, 2009; Solesvik et al., 2012). In preparing behavioral control instruments, the challenges or conveniences faced in entrepreneurship were emphasized. Respondents were asked to assess how comfortable they were in entrepreneurship.

\section{RESULT AND DISCUSSION}

\section{Specific Profile of Respondents}

The research survey was conducted to 631 university students who took entrepreneurship and management subject. The total sample was classified based on gender; male with 356 students and female with 275 students. Next attribute, we classified based on the study level which we classified into four different levels. The final attribute, we concluded that 319 individuals or 50.56 percent had an entrepreneur family background, while 312 individuals or 49.44 percent had a non-entrepreneur family background. The respondent details can be seen in Table 2 .
IVC (0.758), PAT (685), PBC (0.764), SUB (0.668), and ATT (0.740).

Table 3. Validity, Discriminant Validity and Reliability Test Results

\begin{tabular}{lccccc}
\hline & IVC & PAT & PBC & SUB & ATT \\
\hline C.R & .914 & .873 & .893 & .824 & .877 \\
AVE & .758 & .685 & .764 & .668 & .740 \\
\hline & & & PBC & SUB & ATT \\
\hline PBC & & & .874 & .780 & .561 \\
SUB & & & .780 & .817 & .645 \\
ATT & & & .561 & .645 & .860 \\
\hline
\end{tabular}

Moreover, to measure the data reliability, a Critical Ratio (CR), which requires the value obtained to be greater than 0.7 , was used. The test results show that the values obtained are entirely greater than the required $\mathrm{CR}$ value, namely IVC (0.914), PAT (0.873), PBC (0.893), SUB (0.824), and ATT (0.877). Thus, it can be concluded that the data obtained is valid and reliable.

Table 2. Description of Respondents

\begin{tabular}{llccc}
\hline Attribute & & Sample & Percent (\%) & Cumulative (\%) \\
\hline Gender & Male & 356 & 56.42 & 56.42 \\
\multirow{3}{*}{ Study Level } & Female & 275 & 43.58 & 100 \\
& First-year & 198 & 31.38 & 31.38 \\
& Second-year & 235 & 37.24 & 68.62 \\
& Third-year & 160 & 25.35 & 93.97 \\
Family Background & Final-year & 38 & 6.02 & 100 \\
& Non-Entrepreneur & 312 & 49.44 & 49.44 \\
& Entrepreneur & 319 & 50.56 & 100 \\
\hline
\end{tabular}

\section{Testing Validity and Reliability}

Table 3 show that the survey results are valid and reliable. The data should meet the specified requirements to determine validity and reliability. The greater the calculated value, the more valid the data obtained. The validity of the data is measured using the Average Variance Extracted (AVE), which requires the values obtained to be greater than 0.5 . The testing results that obtained AVE values of more than 0.5 are
Another tool used to determine the validity of the data is to test the discriminant validity. Discriminant validity requires AVE squared value to be greater than the correlation between different variables. Table 3 shows that the AVE squared values are greater than the correlation value between different variables. PBC, SUB, and ATT values are $0.874,0.817$, and 0.860 respectively, while the values between different variables are $\mathrm{PBC}<->$ SUB $(0.780), \mathrm{PBC}<->\mathrm{ATT}$ (0.561), and SUB <-> ATT (0.645). Therefore, 
Ambara Purusottama \& Teuku Fajar Akbar/ Entrepreneurship Preference among University Students: an....

based on several data testing tools that had been carried out, it can be seen that the data obtained is valid and reliable to be continued to the next testing process. The result of general hyphothesis testing shown in Figure 3.
(NFI), Relative Fit Index (RFI), Comparative Fit Index (CFI), Tucker Lewis Index (TLI), and Goodness of Fit Index (IFI). These models are good if the indicator values are close to 1 . Table 4 shows that the value of the indicators is close

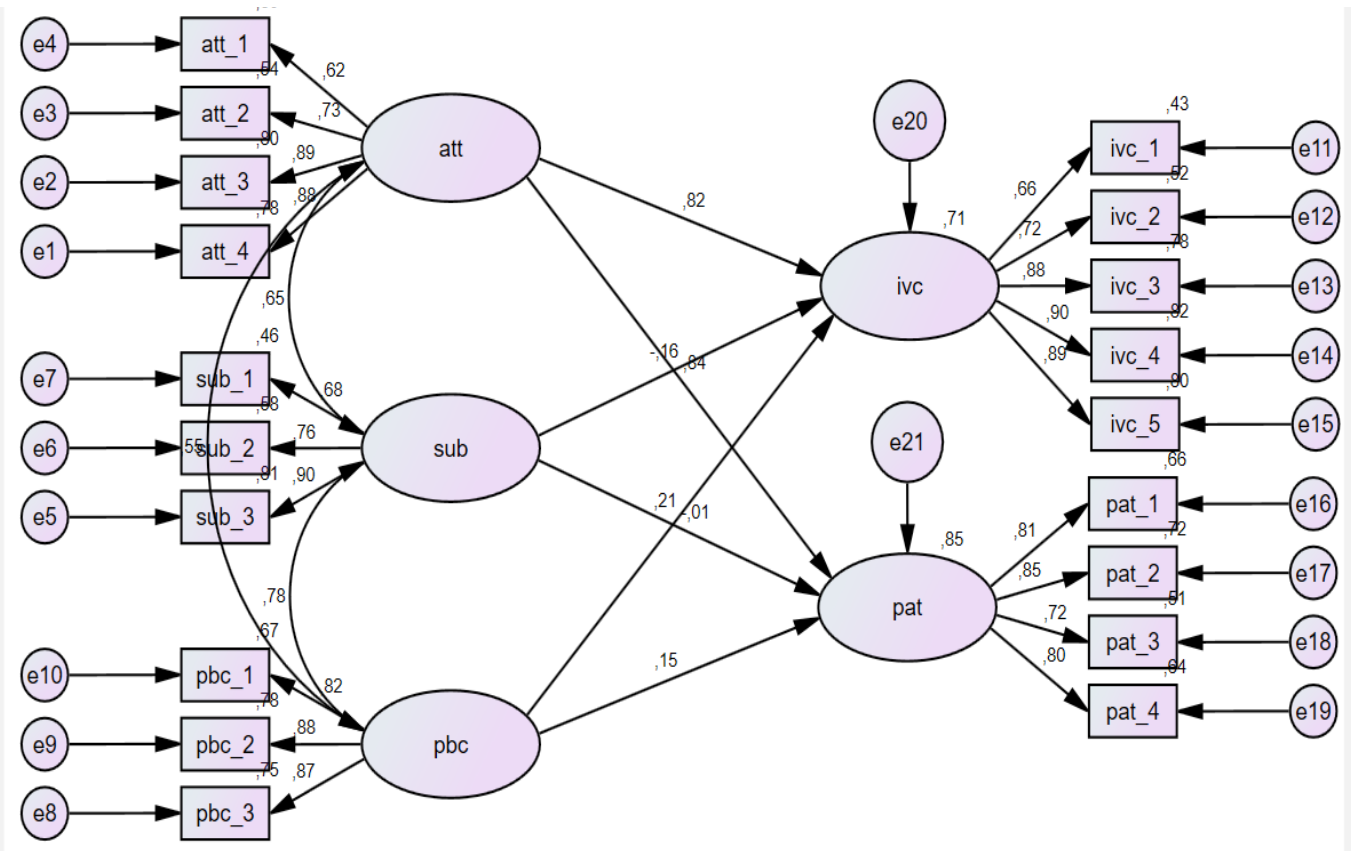

Figure 3. General Hypothesis Testing Result

\section{Goodness-of-Fit Model Index}

The sample size that exceeds 400 respondents makes the Chi-Square (CMIN) and CMIN/DF scores unsuitable for measuring the fitness of models of the existing data (Hair et al., 2010). Although the Chi-Square results are still within the specified range, for our purpose, it will be better to use other measurement methods.

Measuring model accuracy can be done with the indicators of the Normative Fit Index to 1 , even though some are below standard 0.9, meaning that the model is enough to represent the data and the model.

Another indicator that was used is RMSEA (Root Mean Square Error of Approximation), which tempted to fix model mismatch. The RMSEA value between 0.05 and 0.08 indicates a good index for accepting the suitability of a model. According to Hair et al. (2010), if the RMSEA value of a model is below 0.08 , the model is accepted as a

Table 4. Goodness-of-fit Model Index

\begin{tabular}{llll}
\hline Indicator & Match Level Target & Estimation Result & Fit Measurement \\
\hline $\mathrm{X}^{2}$ & $\leq 2-5$ & $\mathrm{X}^{2} / d f=3.740$ & Good fit \\
NFI & $>.92$ & .960 & Good Fit \\
CFI & $>.92$ & .970 & Good Fit \\
TLI & $>.92$ & .961 & Good Fit \\
RMR & .08 or less (with CFI above .92) & .062 & Good Fit \\
RMSEA & Values $<.08$ & .066 & Good Fit \\
GFI & $>.90$ & .952 & Good Fit \\
\hline
\end{tabular}


good model. The RMSEA value will be considered better if it is closer to the value of 0 . If the distribution and the number of data samples are high, the RMSEA value has the potential to increase. Thus, based on the analysis of Table 4, this model can be summed up as good to represent the model.

\section{General Hypothesis Testing}

Table 5 shows fairly consistent results. $\mathrm{ATT}$ and $\mathrm{PBC}$ variables have a significant influence on the endogenous variables, IVC, and PAT. In contrast, in the SUB variable showed varied results on the endogenous variable; IVC is significant, while PAT is not. Nevertheless, the significance produced is quite varied. The relationships between SUB toward IVC and PBC to PAT are different from the relationships between other variables which fulfill at 0.01 (99\% confidence level). When the rules of trust were made a level higher, the relationship between these variables was no longer significant. Thus, it can be concluded that the hypotheses Hal, Ha2, Ha3, Ha5, and Ha6 are accepted, while Ha6 is not accepted or rejected.
The results of hypothesis testing show that family background has a dominant influence on the entrepreneurial intention from the perspective of ATT. The domination of ATT is expressed by the regression coefficient value of 0.801 toward IVC and 0.820 toward PAT. This is followed by PBC with the resulting coefficient value of 0.362 toward IVC and 0.277 toward PAT. SUB becomes the variables that give the weakest influence with a coefficient of 0.292 toward IVC and 0.111 toward PAT. However, these relationships between SUB with the endogenous variables, IVC and PAT, have inverse relationships, expressed by the negative sign.

\section{Family Background Hypothesis Testing}

The testing of family backgrounds as non-entrepreneur and entrepreneur is shown in Table 6. In non-entrepreneur families, only the relationship between ATT and endogenous variables is significant. None of the relationships between SUB and PBC, and none of the endogenous variables is significant. It is proven that there is no P-value produced that meets the specified minimum significance standard (95\%),

Table 5. General Hypothesis Testing Results

\begin{tabular}{lllllll}
\hline Hypothesis & \multicolumn{2}{l}{ Relationship } & & Estimate (S) & P-Value & Decision \\
\hline Ha1 & ATT & $-->$ & IVC & .801 & $* * *$ & $S^{* * *}$ \\
Ha2 & ATT & $-->$ & PAT & .820 & $* * *$ & $S^{* * *}$ \\
Ha3 & SUB & $-->$ & IVC & -.292 & .006 & $S^{* *}$ \\
Ha 4 & SUB & $-->$ & PAT & -.111 & .225 & NS \\
Ha5 & PBC & $-->$ & IVC & .362 & A $^{* * *}$ & $S^{* * *}$ \\
Ha6 & PBC & $-->$ & PAT & .277 & .003 & $S^{* *}$ \\
\hline
\end{tabular}

(S) Supported; (NS) Not Supported; ${ }^{*}$ significant in 0,05 (two-tailed) or $95 \%$ confidencelevel; ${ }^{* *}$ significant in 0,01; ${ }^{* *}$ significant in 0,001

Table 6. Hypothesis Testing Families Non-Entrepreneur vs Entrepreneur

\begin{tabular}{|c|c|c|c|c|c|c|c|c|c|}
\hline \multirow{2}{*}{ Hypothesis } & \multirow{2}{*}{\multicolumn{3}{|c|}{ Relationship }} & \multicolumn{2}{|l|}{ Estimate } & \multicolumn{2}{|l|}{ P-Value } & \multicolumn{2}{|l|}{ Decision } \\
\hline & & & & Non-Entre & Entre & Non-Entre & Entre & Non-Entre & Entre \\
\hline Ha1 & ATT & $->$ & IVC & 0.805 & 0.806 & *** & $* * *$ & $\mathrm{~S}^{* * *}$ & $S^{* * *}$ \\
\hline $\mathrm{Ha} 2$ & $\mathrm{ATT}$ & $-->$ & PAT & 0.803 & 0.832 & $* * *$ & $* * *$ & $S^{* * *}$ & $S^{* * *}$ \\
\hline Ha3 & SUB & $-->$ & IVC & -0.140 & -0.387 & 0.305 & 0.006 & NS & $\mathrm{S}^{* *}$ \\
\hline Ha4 & SUB & $->$ & PAT & 0.014 & -0.162 & 0.914 & 0.152 & NS & NS \\
\hline Ha5 & $\mathrm{PBC}$ & $->$ & IVC & 0.202 & 0.451 & 0.147 & 0.002 & NS & $S^{* *}$ \\
\hline Ha6 & $\mathrm{PBC}$ & $-->$ & PAT & 0.150 & 0.336 & 0.238 & 0.003 & NS & $S^{* *}$ \\
\hline
\end{tabular}


namely SUB toward IVC (0.305) and PAT (0.914), and PBC toward IVC (0.147) and PAT (0.238). On the other hand, the entrepreneur families produce more significant relationships. SUB and PAT, however, does not have a significant relationship. In short, entrepreneurial families provide more exposure to students' entrepreneurial intentions.

Between non-entrepreneur and entrepreneur family backgrounds, similar factors have a major influence on the students' entrepreneurial intention. ATT variable has the largest coefficient among other variables. In non-entrepreneur families, the ATT coefficient for the endogenous variable has a value of 0.805 (IVC) and 0.803 (PAT). On the other hand, in entrepreneur families, ATT value coefficients are 0.806 for IVC and 0.832 for PAT.

From the perspective of $\mathrm{PBC}$, the coefficients of $\mathrm{PBC}$ of non-entrepreneur families towards IVC and PAT are 0.202 and 0.150 , respectively. In contrast, the coefficients of $\mathrm{PBC}$ of entrepreneur family toward IVC and PAT are 0.451 and 0.336 , respectively. SUB variable becomes the weakest among the other variables. In non-entrepreneur families, the coefficient values of the SUB variable on the endogenous variables are 0.140 and 0.014 . In entrepreneur families, the SUB variable produces a coefficient of 0.387 (IVC) and 0.162 (PAT). Almost all of the SUB variables have a reverse relationship with the endogenous variables, marked by the negative sign.

\section{Discussion}

The results of the analysis show that EEP is able to give a positive emphasis on student entrepreneurial preferences, both intention to value creation (starting up a new business) and entrepreneur as a professional attraction (Fayolle, 2013; Fayolle \& Gailly, 2015; Purusottama \& Akbar, 2019). With regard to value creation, the three factors that influence TPB-attitude, subjective norms, and perceived behavioral control -are not all able to bring a positive and significant influence on value creation. Social environmental factors, on the other hand, although having a significant influence, illustrate the existence of a negative relationship. From the attitude factor, EEP brought upon to students is able to be captured positively by students. Students consider that establishing a new business (value creation) is a good thing and will have a positive influence on them. Despite of having no experience in entrepreneurship, the knowledge provided through EEP has a significant impact on students' entrepreneurial preferences (Küttim et al., 2014), higher education institutions and students. Entrepreneurship education has been shown to contribute to the development of students' entrepreneurial intentions, although the findings are not entirely conclusive. The theoretical foundation of the current paper was the theory of planned behavior, TPB (Ajzen, 1991, 2005). This situation also occurs in controlling individual behavior to establish new ventures.

EEP is indeed able to provide tacit knowledge to students to create new ventures. Even though practicing entrepreneurship has indeed many challenges, students are able to turn those hurdles into a source of opportunity in the endeavor of creating valuable businesses (Kautonen et al., 2015). However, the two factors that were mentioned previously are not in line with social environmental factors and subjective norms. Social environmental factors actually provide the opposite relationship (Purusottama, 2019). There is a disharmony between social environmental opinion and student preferences to open up new businesses. With the presence of the EEP, it has increasingly sharpened its incompatibility with social environment. The social environment is not at all supportive and tends to be against the notion of creating a new business because they argue that it is full of risks and uncertainty. Through the lens of the social environment, creating a new business requires no small amount of capital, i.e., monetary capital and human capital. In addition, the social environment assumes that students do not have the ability to manage new businesses that will be run by them. Similar results also occur in entrepreneurial preferences in the context of job attractiveness. 
Similarities that occur are social environmental factors that also do not support the notion of student preferences to be an entrepreneur. Although this thinking is not as radical as the preference for establishing a new business, there exists a similar disharmony between the support of the surrounding environment and individual entrepreneurial preferences. The social environment advises students not to have a preference for becoming an entrepreneur. The profession of being an entrepreneur is perceived negatively by the social environment because it is full of uncertainty. Other factors that influence student preferences for being an entrepreneur include attitude and perceived behavioral control. Both factors turned out to have a positive influence on the students. The EEP is able to provide an understanding that being an entrepreneur is positive and provides benefits for the students. In addition, EEP is also able to provide positive behavioral control. Even though being an entrepreneur is packed with intriguing challenges, students perceive that they are able to change these challenges to be converted into job attractiveness preferences.

The results turned out to produce the same findings when grouped from the background of family (parents) work. The findings show that based on family work, not all factors have a significant and positive influence on student entrepreneurial preferences, regarding the decision to create a business or to work as an entrepreneur (Bosma et al., 2012; Castro et al., 2015; Eesley \& Wang, 2017). Of the three factors of TPB, only two factors have a positive influence on entrepreneurial preferences i.e., attitude and perceived behavioral control. Contrary to the two previous factors, social environmental factors have a negative influence on student entrepreneurial preferences. The family's work background does not guarantee that the students will be free from the negative opinions coming from the social environment comparing to families (parents) who have entrepreneurial backgrounds. The students' surrounding social environments do not recommend them to create new businesses or for them to become entrep- reneurs. The unpleasant experience of being an entrepreneur, which consumes a great amount of time to achieve monetary success, is perhaps one of the main reasons for the lack of support from the social environment. As a result, families with an entrepreneurial background have a striking difference from families with a non-entrepreneurial background.

From the perspective of students with non-entrepreneurial family backgrounds, only one of the three factors influence student entrepreneurial preferences. The EEP is only able to give a positive emphasis on one factor i.e., the attitude factors. The successful competence of the EEP against non-entrepreneurial family is not able to contribute much to the entrepreneurial preferences of students. The EEP does not have the ability to provide students with the general understanding that entrepreneurial preferences tend to be positive and could provide valuable benefits for them in the future. Moreover, the challenges of the non-entrepreneurial family cannot be changed by EEP interventions. It turns out that entrepreneurial parents are not able to provide good examples of entrepreneurship practices in everyday life towards their child, which in turn will not also change entrepreneurial preferences that their child has.

\section{CONCLUSION AND RECOMMENDATION}

Up until this very moment, the study of EEP on entrepreneurship is a topic that is still heavily discussed. As one of the key performance indicators of the most country, including Indonesia, entrepreneurship enhancement has indeed become a catchphrase nowadays. Indonesia is one country in South East Asia that is trying to implement the EEP to catch up with other ASEAN countries. However, efforts to implement EEP face many challenges because the effectiveness of EEP on a global scale is still polemic. The findings show that the effectiveness of EEP is able to provide a positive understanding of entrepreneurial preferences. Of the three factors that influence entrepreneurial preferences, both the creation of new busines- 
ses and profession attractiveness, EEP is able to give a positive emphasis on attitude and behavior control factors. Conversely, social environmental factors bring a negative emphasis to the table. Similar findings were scrutinized from the point of view of entrepreneurial families. On one hand, the finding is quite surprising because it turns out that despite having an entrepreneurial background, the students' social environment does not suggest the preference to become an entrepreneur. On the other hand, with non-entrepreneurial families, EEP is only able to emphasize the attitude factor. Despite the interesting findings, this study has encountered limitations.

The limitations we meet are quite diverse and can be brought about in future research. Firstly, the research we conducted was cross-sectional so that it was not able to capture the full EEP role of each student. Furthermore, we realize that the orientation of education focuses on the process rather than the output. We recommend using a longitudinal research approach to capture the full EEP picture of students. Secondly, the context of the research area that we worked on is still very limited. We used Jabodetabek as the main area in our research. Differences in implementation and understanding of the EEP were our main concern so that the results of research conducted were not able to answer problems in other regions. We realize that context is a basic foundation in social science research. We suggest conducting research with a wider area so that they can draw conclusions about the results of research in the context of greater Indonesia. Finally, this research, unfortunately, was only able to capture a general phenomenon. We urge to use the interpretive approach to dig deeper into the surprising and interesting findings in this study. But in the midst of the limitations we face, we believe that this research provides sufficient contribution.

This research is able to contribute positively to the theory and also to the world of practitioners and decision-makers in the go- vernment. This research contributes to the enrichment in the scientific theory of planned behavior (TPB) and also in the scope of entrepreneurship education. Specifically, the results of this study can bridge the EEP polemic that is still being discussed by using the entrepreneurial preference variable. In practical terms, this research can be used as a reference regarding the success or failure of EEP implementation in Indonesia. If it is considered successful from the sample we use, the EEP curriculum can be duplicated and modified to suit the contextual areas of other regions in Indonesia. However, if it is considered unsuccessful, then there needs to be a readjustment to the education curriculum so that the application of EEP can be more effective.

\section{REFERENCES}

Ajzen, I., \& Sheikh, S. (2013). Action Versus Inaction: Anticipated Affect in the Theory of Planned Behavior. Journal of Applied Social Psychology, 43(1), 155-162.

Böckenholt, U. (2017). Measuring Response Styles in Likert Items. Psychological Methods, 22(1), 69-83.

Bosma, N., Hessels, J., Schutjens, V., Praag, M. Van, \& Verheul, I. (2012). Entrepreneurship and Role Models. Journal of Economic Psychology, 33(2), 410-424.

Castro, M., Expósito-Casas, E., López-Martín, E., Lizasoain, L., Navarro-Asencio, E., \& Gaviria, J. L. (2015). Parental Involvement on Student Academic Achievement: a Meta-Analysis. Educational Research Review, 14(February 2015), 33-46.

Eesley, C., \& Wang, Y. (2017). Social Influence in Career Choice: Evidence from a Randomized Field Experiment on Entrepreneurial Mentorship. Research Policy, 46(3), 636-650.

Fayolle, A. (2013). Personal Views on the Future of Entrepreneurship Education. Entrepreneurship and Regional Development, 25(7-8), 692-701.

Fayolle, A., \& Gailly, B. (2015). The Impact of Entrepreneurship Education on Entrepreneurial Attitudes and Intention: Hysteresis and Persistence. Journal of Small Business Management, 53(1), 75-93. 
Gorgievski, M. J., Stephan, U., Laguna, M., \& Moriano, J. A. (2018). Predicting Entrepreneurial Career Intentions: Values and the Theory of Planned Behavior. Journal of Career Assessment, 26(3), 457-475.

Hair, J. F., Black, W. C., Babin, B. J., \& Anderson, R. E. (2010). Multivariate Data Analysis: International Version. New Jersey: Pearson.

Kautonen, T., Van Gelderen, M., \& Fink, M. (2015). Robustness of the Theory of Planned Behavior in Predicting Entrepreneurial Intentions and Actions. Entrepreneurship: Theory and Practice, 39(3), 655-674.

Küttim, M., Kallaste, M., Venesaar, U., \& Kiis, A. (2014). Entrepreneurship Education at University Level and Students' Entrepreneurial Intentions. Procedia-Social and Behavioral Sciences, 110(2014), 658-668.

Liñán, F., \& Chen, Y.-W. (2009). Development and Cross-Cultural Application of a Specific Instrument to Measure Entrepreneurial Intentions. Entrepreneurship Theory and Practices, 33(3), 593-617.

Liñán, F., Rodríguez-Cohard, J. C., \& Rueda-Cantuche, J. M. (2011). Factors Affecting Entrepreneurial Intention Levels: a Role for Education. International Entrepreneurship and Management Journal, 7(2), 195-218.

Miralles, F., Giones, F., \& Gozun, B. (2017). Does Direct Experience Matter? Examining the Consequences of Current Entrepreneurial Behavior on Entrepreneurial Intention. International Entrepreneurship and Management Journal, 13(3), 881-903.

Nabi, G., Liñán, F., Fayolle, A., Krueger, N., \& Walmsley, A. (2017). The Impact of Entrepreneurship Education in Higher Education: a Systematic Review and Research Agenda. Academy of Management Learning \& Education, 16(2), 277-299
Nielsen, S. L., \& Gartner, W. B. (2017). Am I a Student and/or Entrepreneur? Multiple Identities in Student Entrepreneurship. Education and Training, 59(2), 135-154.

Purnomo, M. (2015). Dinamika Pendidikan Kewirausahaan: Pemetaan Sistematis terhadap Pendidikan, Pengajaran dan Pembelajaran Kewirausahaan. Jurnal Dinamika Manajemen, 6(1), 97-120.

Purusottama, A. (2019). Revisiting Students' Entrepreneurial Intention in Indonesia: a Theory of Planned Behavior Approach. Jurnal Manajemen dan Kewirausahaan, 21(1), 64-73.

Purusottama, A., \& Akbar, T. F. (2019). An Entrepreneurship Education Model for Promoting Students' Entrepreneurial Intentions: the Case of Indonesian Higher Education. Indonesian Journal of Business and Entrepreneurship, 5(2), 138-147.

Schlaegel, C., \& Koenig, M. (2014). Determinants of Entrepreneurial Intent: a Meta-Analytic Test and Integration of Competing Models. Entrepreneurship: Theory and Practice, 38(2), 291-332.

Solesvik, M. Z., Westhead, P., Kolvereid, L., \& Matlay, H. (2012). Student Intentions to become Self-Employed: the Ukrainian Context. Journal of Small Business and Enterprise Development, 19(3), 441-460.

Souitaris, V., Zerbinati, S., \& Al-Laham, A. (2007). Do Entrepreneurship Programmes Raise Entrepreneurial Intention of Science and Engineering Students? the Effect of Learning, Inspiration and Resources. Journal of Business Venturing, 22(4), 566-591.

Westhead, P., \& Solesvik, M. Z. (2016). Entrepreneurship Education and Entrepreneurial Intention: Do Female Students Benefit? International Small Business Journal: Researching Entrepreneurship, 34(8), 979-1003. 